九州大学学術情報リポジトリ

Kyushu University Institutional Repository

\title{
Plant production and water purification efficiency by rice and umbrella plants grown in a floating culture system under various water environmental conditions
}

Miyazaki, Akira

Laboratory of Plant Production Physiology, Division of Soil Science and Plant Production, Department of Plant Resources, Faculty of Agriculture, Kyushu University

Kubota, Fumitake

Laboratory of Plant Production Physiology, Division of Soil Science and Plant Production, Department of Plant Resources, Faculty of Agriculture, Kyushu University

Agata, Waichi

Laboratory of Plant Production Physiology, Division of Soil Science and Plant Production, Department of Plant Resources, Faculty of Agriculture, Kyushu University

Yamamoto, Yoshinori

Faculty of Agriculture, Kochi University

他

https://doi.org/10.5109/24354

出版情報：九州大学大学院農学研究院紀要. 45 (1)，pp.29-38，2000-11. Kyushu University バージョン：

権利関係 : 


\title{
Plant production and water purification efficiency by rice and umbrella plants grown in a floating culture system under various water environmental conditions
}

\author{
Akira Miyazaki, Fumitake Kubota, Waichi Agata, \\ Yoshinori Yamamoto* and Xiangfu Song**
}

\begin{abstract}
Laboratory of Plant Production Physiology, Division of Soil Science and Plant Production, Department of Plant Resources, Faculty of Agriculture, Kyushu University, Fukuoka 812-8581, Japan; *Faculty of Agriculture, Kochi University, Nankoku 783-8502, Japan; **China National Rice Research Institute, Hangzhou 310006, China (Received July 25, 2000 and accepted August 18, 2000)
\end{abstract}

\begin{abstract}
The floating culture system was originally designed with a purpose of developing a new cropping area by growing plants on the water surface; in addition, this system can also be used as a technique for water purification by allowing plants to absorb nutrients from the eutrophied water. We investigated here the specific differences in water purification effect and plant productivity of rice and umbrella plants both of which were grown on the surface of the waters with various levels of eutrophication. The results were as follows: 1) In both species, the rate of nitrogen absorption (NR) was positively related to the crop growth rate (CGR). Both parameters greatly changed in value with water conditions, showing a negative relation with $\mathrm{pH}$ and positive relation with electrical conductivity (EC). 2) Application of a slow-release fertilizer as basal dressing to rice in the eary growth stage had a beneficial effect on subsequent growth vigor, and the highest grain yield of rice was $542 \mathrm{~g} \mathrm{~m}^{2}$ comparable to the yield obtained in paddy-grown plants. The leaf photosynthetic rate, chlorophyll content and plant weight were increased, depending on the water quality, by applying acid and iron controlling chemicals together with the basal-dressing fertilizer. High $\mathrm{pH}$ caused an iron deficiency in rice and greatly restricted its growth. In the eutrophied waters, iron fertilizer application to plants was very effective in improving the growth. 3) CGR and water purification effect of umbrella plants were significantly superior to those of rice examined under all of the growth conditions in this study. The water purification by umbrella plants is practically expected in eutrophied water areas.
\end{abstract}

\section{INTRODUCTION}

Eutrophication of lakes and ponds is often caused by industrial and residential wastes and agricultural runoff including high concentrations of N, P and organic matters. Due to enhancement in water eutrophication and its resultant proliferation of phytoplankton, the levels of biochemical oxygen demand (BOD) and chemical oxygen demand (COD) increase. Furthermore, this process becomes a cause of the production of poisonous gases from organic matter accumulated in the deposited layer in the water. The decomposition of organic matter is responsible for reducing oxygen concentration and further enrichment in $\mathrm{N}$ and $\mathrm{P}$ in the water. This promotes the growth of algae or hydrophytes, causing biomass accumulation in the water ecosystem. If this vicious circle is continuously repeated in the closed water environment, the level of eutrophication may constantly increase with time.

The floating culture system used in the present study was originally developed to grow crop plants and yield their products on the water surface of lakes and rivers. Now 
this system has been reevaluated as a technique useful for water purification by allowing plants to absorb nutrients from the eutrophied water (Song et al. 1991, 1995). The nutrients absorbed by plants are taken out of the ecosystem in the water by harvesting the products. This is regarded as an effective technique for reducing and cutting the vicious circle of water pollution. In a previous study, yield production and water purification performance were investigated using rice grown in eutrophied lakes and ponds (Song et al. 1994). By conducting further screenings with many plants, umbrella plant was identified to be a species with most vigorous growth in the floating culture system and has been predicted as a promising plant for water purification (Miyazaki et al. 1995, 1997).

The biomass production and water purification effects of plants used in this system are thought to differ with water environmental conditions, depending on the amount of nutrients flowing into the water area and change in $\mathrm{pH}$. In order for the floating culture system to be practically introduced as a water purification technique, further studies are required to clarify the relationships between plant growth and environmental factors in the water. Of the many factors having great effects on plant growth, $\mathrm{pH}$, nutrients and their combinations were focused here, and the growth characteristics and water purification effects of rice and umbrella plants were compared and discussed.

\section{MATERIALS AND METHODS}

A series of experiments (experiments $\mathrm{A} \sim \mathrm{H}$ ) was carried out from 1994 to 1999 at eight locations in Japan: Giro lake in Nagoya, experimental water reservoirs at Kyushu University in Fukuoka, and sewage treatment ponds and experimental reservoirs at Kochi University. Table 1 shows the water qualities in experiments $\mathrm{A} \sim \mathrm{H}$, where $\mathrm{pH}, \mathrm{EC}$, $\mathrm{NO}_{3}-\mathrm{N}$ and $\mathrm{NH}_{4}-\mathrm{N}$ were in the ranges of $6.9 \sim 8.4,0.1 \sim 0.8 \mathrm{mS} \mathrm{cm}{ }^{-1}, 0.01 \sim 3.2 \mathrm{mg} \mathrm{L}^{-1}$ and $0.1 \sim 47 \mathrm{mg} \mathrm{L}^{-1}$, respectively. Rice, Oryza sativa L. cv. Nipponbare, and umbrella plant, Cyperus alternifolius L., were grown in the floating culture system on the water surface. Twenty-to-35-day-old seedlings of rice and young seedlings of umbrella plants with 2 or 3 stems were inserted into the planting holes opened through the styrofoam float board, and the culm base of each plant was fixed by foam rubber at the middle depth of the hole (Miyazaki et al. 1995). Two rice plants per hole and one umbrella plant per hole were transplanted and grown. Fig. 1 shows rice plants grown in the floating culture system.

A slow-release fertilizer (N, 13\%; P, 11\%; K, 13\%; Longtotal 100, Chisso Asahi Fertilizer Co.) was placed $2 \mathrm{~g}$ per hill, as basal-dressing, in the foam rubber at the time of transplantation. In addition, the same fertilizer, $2 \mathrm{~g}$ per hill as top-dressing, was once applied to both species at 10 to 19 days before heading time of rice. Three fertilizing regimes (no fertilizer, basal-dressing, and basal plus top-dressing) were employed for rice in 1994 and for both species in 1995, 1997 and 1999.

In 1994, the growth characteristics and yield of float-cultured and paddy-cultured rice plants were compared. The amounts of fertilizers used for $\mathrm{N}, \mathrm{P}$ and $\mathrm{K}$ in the paddy field were 2,2 , and $2 \mathrm{~kg} / 10 \mathrm{a}$ as basal-dressing and $4.2,6$, and $3.6 \mathrm{~kg} / 10 \mathrm{a}$ as top-dressing, respectively. Top-dressing was applied 3 times, 28 days after transplanting, and 18 and 8 days before heading.

The effects of application of acid fertilizer including $1.0 \%$ of $\mathrm{SO}_{3}(\mathrm{pH}$ mix; Kureha 
Plant production and water purification efficiency by rice and umbrella plants grown in a floating culture system

Table 1. Water quality in the experimental reservoirs.

\begin{tabular}{|c|c|c|c|c|c|c|c|c|c|c|}
\hline Ex. & Year & Place & $\begin{array}{l}\text { Water } \\
\text { rea }\left(\mathrm{m}^{2}\right)\end{array}$ & $\begin{array}{c}\text { Plant } \\
\text { species }\end{array}$ & $\mathrm{pH}$ & $\begin{array}{c}\mathrm{EC} \\
\left(\mathrm{mS} \mathrm{cm}^{1}\right)\end{array}$ & $\begin{array}{c}\mathrm{DO} \\
\left(\mathrm{mg} \mathrm{L}^{-1}\right)\end{array}$ & $\begin{array}{c}\mathrm{NO}_{3}-\mathrm{N} \\
\left(\mathrm{mg} \mathrm{L}^{-1}\right)\end{array}$ & $\begin{array}{c}\mathrm{NH}_{4}-\mathrm{N} \\
\left(\mathrm{mg} \mathrm{L}^{-1}\right)\end{array}$ & $\begin{array}{l}\text { Total P } \\
\left(\mathrm{mg} \mathrm{L}^{-1}\right)\end{array}$ \\
\hline $\mathrm{A}$ & 94 & Kyushu Univ., Fukuoka & 60 & $\mathrm{R}$ & 7.19 & 0.76 & 1.5 & 1.73 & 1.6 & 0.38 \\
\hline $\mathrm{B}$ & 94 & Kyushu Univ., Fukuoka & 27 & $R$ & 7.07 & 0.48 & 1.0 & 0.48 & 0.2 & 0.07 \\
\hline $\mathrm{C}$ & 95 & Kyushu Univ., Fukuoka & 12 & $\mathrm{R}, \mathrm{U}$ & - & - & - & - & - & - \\
\hline $\mathrm{D}$ & 95 & Giro lake, Nagoya & - & $\mathrm{U}$ & 7.08 & - & 5.5 & 0.10 & 0.1 & 0.20 \\
\hline $\mathrm{E}$ & 97 & Kyushu Univ., Fukuoka & 27 & $\mathrm{R}, \mathrm{U}$ & 7.94 & 0.36 & 8.6 & 0.28 & 0.1 & 0.32 \\
\hline $\mathrm{F}$ & 99 & Sewage works, Nankoku & 200 & $\mathrm{U}$ & 6.92 & 0.77 & 6.0 & 3.21 & 46.6 & 1.04 \\
\hline $\mathrm{G}$ & 99 & Kochi Univ., Nankoku & 50 & $\mathrm{R}, \mathrm{U}$ & 8.06 & 0.11 & 7.5 & 0.01 & 0.3 & 0.03 \\
\hline $\mathrm{H}$ & 99 & Kochi Univ., Nankoku & 49 & $\mathrm{R}, \mathrm{U}$ & 8.41 & 0.19 & 9.9 & 0.09 & 0.5 & 0.10 \\
\hline
\end{tabular}

Ex., Experiment; EC, Electrical conductivity; DO, Dissolved oxygen.

R, Rice; U, Umbrella plant.

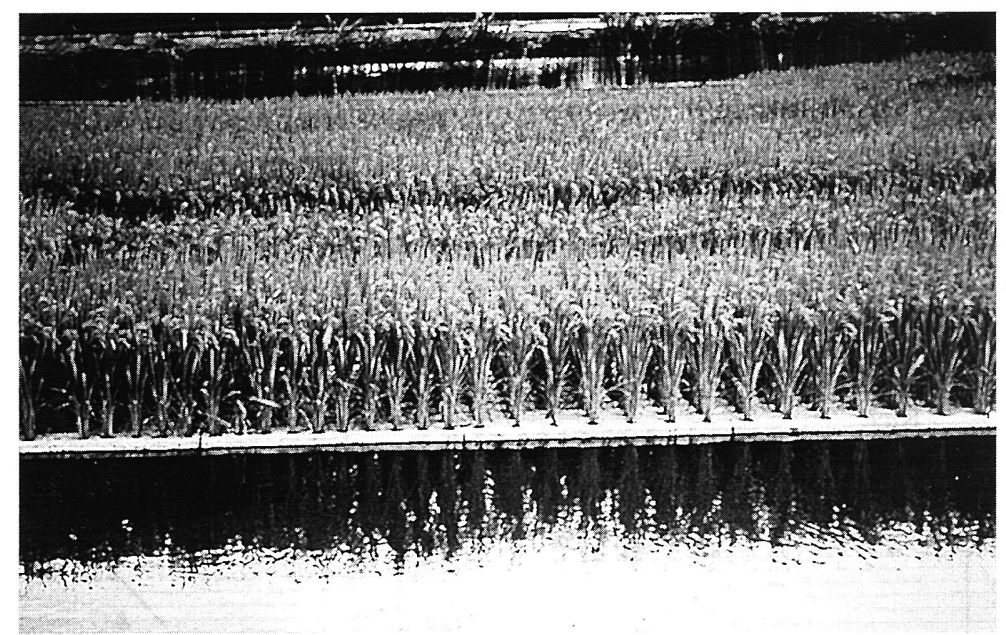

Fig. 1. Photograph of rice grown by the floating culture system.

Chemical Co.) and iron ( $\mathrm{Fe}$ ) fertilizer including 8.8, 0.08 and $0.04 \%$ of $\mathrm{Fe}, \mathrm{Zn}$ and $\mathrm{Cu}$, respectively (Ferrite iron; Japan Ferro Co.) were investigated at experiment E in 1997. Both fertilizers were applied $3 \mathrm{~g}$ per hill to each of plots together with a slow-release fertilizer at the transplanting time. The control plants were grown in a paddy field where a compound fertilizer, including $2.7,2.7$ and $2.7 \mathrm{~kg} / 10 \mathrm{a}$ of $\mathrm{N}, \mathrm{P}$ and $\mathrm{K}$, respectively, was applied as basal-dressing. The photosynthetic rate and chlorophyll content in expanded young leaves and growth parameters were measured on the 38 th day after transplantation.

Plants and residual fertilizer in experiments $\mathrm{A} \sim \mathrm{H}$ were sampled from the planting holes. The sampling was made at the same time (the maturing stage of rice) for both species. The nitrogen $(\mathrm{N})$ concentration in sampled materials was determined by the Kjeldahl method. 
The effect of $\mathrm{N}$ purification (nitrogen absorbed from the water) was calculated from $\mathrm{N}$ weights (NW) included in plants and fertilizers by the following equation.

$\mathrm{N}$ purification effect=NW in plant $-\mathrm{NW}$ dissolved from fertilizer

NW dissolved from fertilizer=NW in applied fertilizer-NW in residual fertilizer

Four parameters, $\mathrm{pH}$, electrical conductivity (EC), dissolved oxygen (DO) and water temperature, were periodically measured using a water checker (Horiba, U-10) during cultivation periods. $\mathrm{NO}_{3}-\mathrm{N}$ and $\mathrm{NH}_{4}-\mathrm{N}$ in the sampled water were measured by the cadmium reduction method and Nessler's method, respectively. Kjeldahl N, the sum of organic $\mathrm{N}$ and $\mathrm{NH}_{4}-\mathrm{N}$, was determined by Nessler's method after sulfuric digestion. Total $\mathrm{N}$ was calculated as the sum of Kjeldahl $\mathrm{N}$ and $\mathrm{NO}_{3}-\mathrm{N}$. Total $\mathrm{P}$ was determined by the ascorbic acid method after persulfuric digestion.

\section{RESULTS}

CGR and $\mathrm{N}$ absorption rate (NR) in rice and umbrella plants grown in the floating culture system were calculated, and their relationships obtained in the experiments (A H) conducted in 1994 to 1999 are shown in Fig. 2. NR was closely related to CGR in both species. The maximum values of NR and CGR were higher in umbrella plant than in rice, though these parameter values greatly varied depending on the fertilizing level and water environmental condition.
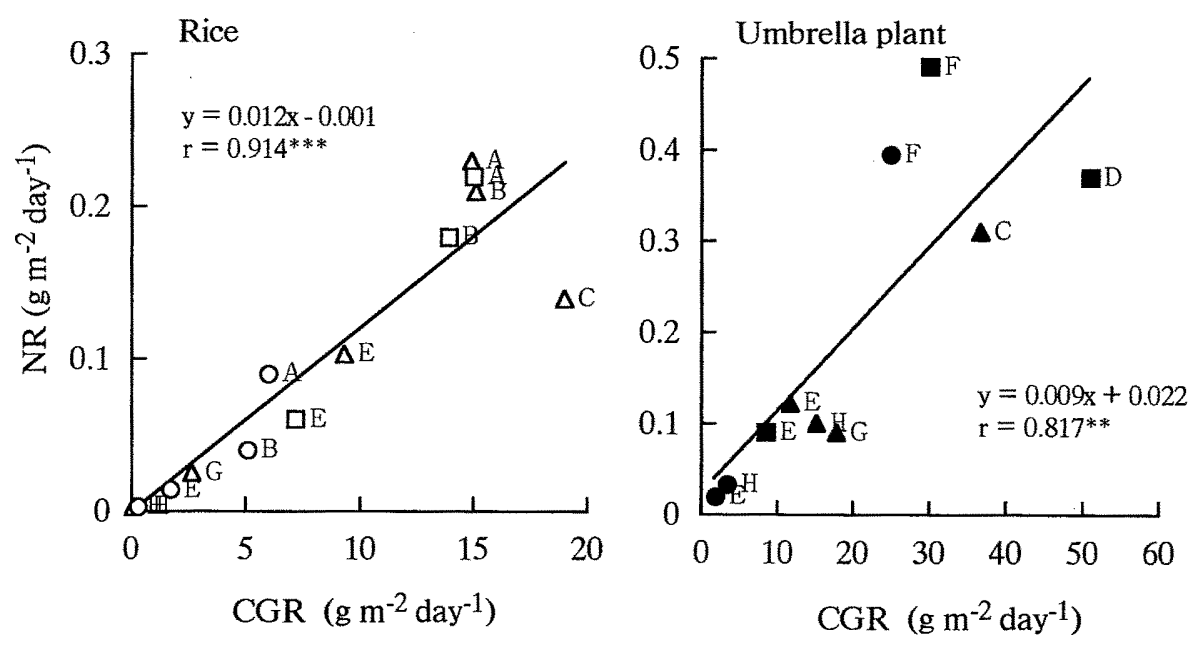

Fig. 2. Relationships between CGR (crop growth rate) and NR (nitrogen absorption rate) in rice and umbrella plants (Experiments $\mathrm{A} \sim \mathrm{H}$ ).

Alphabetical letters in the figures represent the experiments shown in Table 1. ** and ***, Significant at $1 \%$ and $0.1 \%$ levels, respectively.

Rice $(\bigcirc$, No fertilizer; $\square$, Basal dressing; $\triangle$, Basal + Top dressing)

Umbrella plant (, No fertilizer; $\mathbf{\square}$, Basal dressing; $\mathbf{A}$, Basal+Top dressing) 
Fig. 3 shows a comparison of the responses in grain yield and $\mathrm{N}$ purification effect in rice grown at the three fertilizing levels in differently eutrophied water reservoirs (experiments $\mathrm{A}$ and $\mathrm{B}$ ). $\mathrm{N}$ and $\mathrm{P}$ concentrations in the water were higher in experiment A $\left(\mathrm{NO}_{3}-\mathrm{N}, 1.7 \mathrm{mg} \mathrm{L}^{-1} ; \mathrm{NH}_{4}-\mathrm{N}, 1.6 \mathrm{mg} \mathrm{L}^{-1}\right.$; Total-P, $\left.0.38 \mathrm{mg} \mathrm{L}^{-1}\right)$ than that in experiment $\mathrm{B}$ $\left(\mathrm{NO}_{3}-\mathrm{N}, 0.5 \mathrm{mg} \mathrm{L}^{-1} ; \mathrm{NH}_{4}-\mathrm{N}, 0.2 \mathrm{mg} \mathrm{L}^{-1}\right.$; Total-P, $\left.0.07 \mathrm{mg} \mathrm{L}^{-1}\right)$. In plants grown without fertilizer application in experiment $\mathrm{A}$, the grain yield was less than $30 \%\left(174 \mathrm{~g} \mathrm{~m}^{-2}\right)$ of the paddy field cropping $\left(585 \mathrm{~g} \mathrm{~m}^{-2}\right)$. By applying the slow-release fertilizer as basal-dressing, the grain yield increased to a level $\left(531 \mathrm{~g} \mathrm{~m}^{-2}\right)$ comparable to that of plants grown in the paddy field. However, additional top-dressing after the basal-dressing had no or only a little effect on increasing the yield, showing quite a small gain of $11 \mathrm{~g} \mathrm{~m}^{-2}$ over $531 \mathrm{~g} \mathrm{~m}^{-2}$. On the other hand, the grain yield in experiment B was less than $50 \%$ of that in experiment $\mathrm{A}$. The $\mathrm{N}$ purification effect in experiment $\mathrm{A}$ was greater than that in experiment $\mathrm{B}$. $\mathrm{N}$ purification was promoted by basal-dressing, but top-dressing was
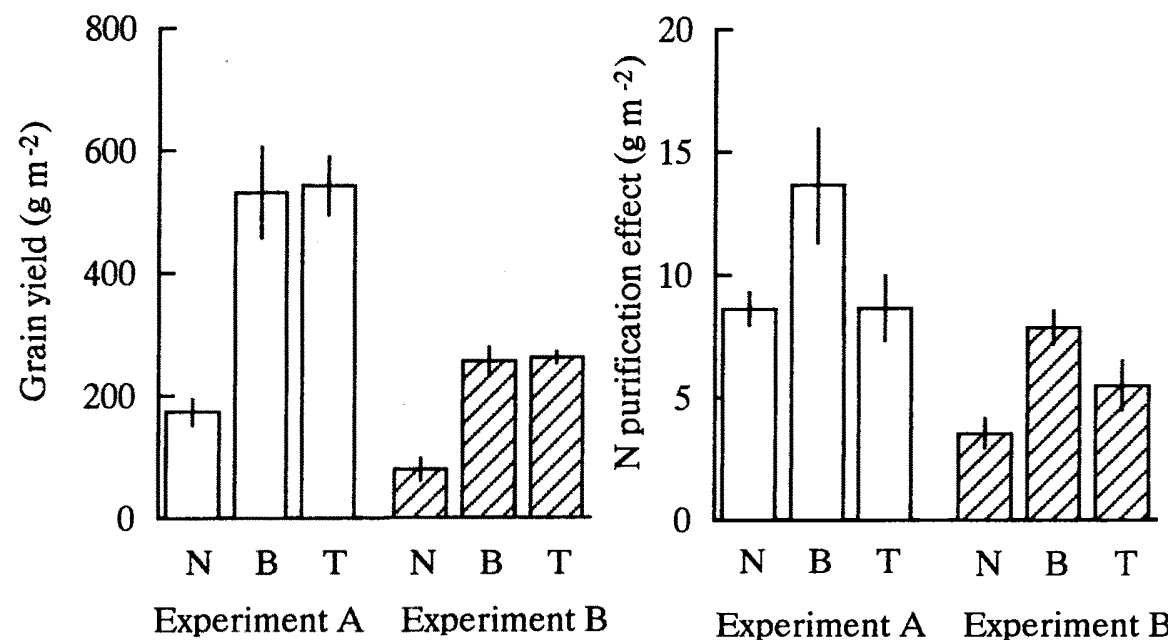

Experiment A Experiment B

Fig. 3. Comparison of grain yield of and nitrogen purification effect in rice grown at different eutrophication levels (Experiments A and B) and fertilizer levels ( N, No fertilizer; B, Basal dressing; T, Basal + Top dressing). Water quality in each experiment is shown in Table 1. Bar indicates standard error.

Table 2. Correlation coefficients between parameters of water quality and CGR of rice and umbrella plants (Experiments $\mathrm{A} \sim \mathrm{H}$ ).

\begin{tabular}{ccccccc}
\hline Species & $\begin{array}{c}\text { Total N } \\
\left(\mathrm{mg} \mathrm{L}^{-1}\right)\end{array}$ & $\begin{array}{c}\text { Total P } \\
\left(\mathrm{mg} \mathrm{L}^{-1}\right)\end{array}$ & $\begin{array}{c}\mathrm{NO}_{3}-\mathrm{N} \\
\left(\mathrm{mg} \mathrm{L}^{-1}\right)\end{array}$ & $\begin{array}{c}\mathrm{NH}_{4}-\mathrm{N} \\
\left(\mathrm{mg} \mathrm{L}^{-1}\right)\end{array}$ & $\mathrm{pH}$ & $\begin{array}{c}\mathrm{EC} \\
\left(\mathrm{mS} \mathrm{cm}^{-1}\right)\end{array}$ \\
\hline $\begin{array}{c}\text { Rice } \\
\text { Umbrella plant }\end{array}$ & $0.605^{*}$ & 0.278 & $0.577^{*}$ & 0.334 & $-0.780^{* *}$ & $0.702^{*}$ \\
\hline
\end{tabular}

$*$ and **, Significant at $5 \%$ and $1 \%$ levels, respectively.

Refer to Table 1 for details of experiments $\mathrm{A} \sim \mathrm{H}$. 
adversely effective on it.

The correlation coefficients between CGR and each parameter of water quality are listed in Table 2. CGR in rice showed a positive relationship with total $\mathrm{N}, \mathrm{NO}_{3}-\mathrm{N}$ and EC, and a negative relationship with $\mathrm{pH}$. CGR of umbrella plant had a negative relationship with $\mathrm{pH}$. The relationship between CGR and fertilizing regimes was varied with $\mathrm{pH}$ and EC levels, as shown in Fig. 4.

CGR in rice showed a negative correlation with $\mathrm{pH}$ and a positive correlation with EC in both fertilized and unfertilized plants. This phenomenon was also detected, though not
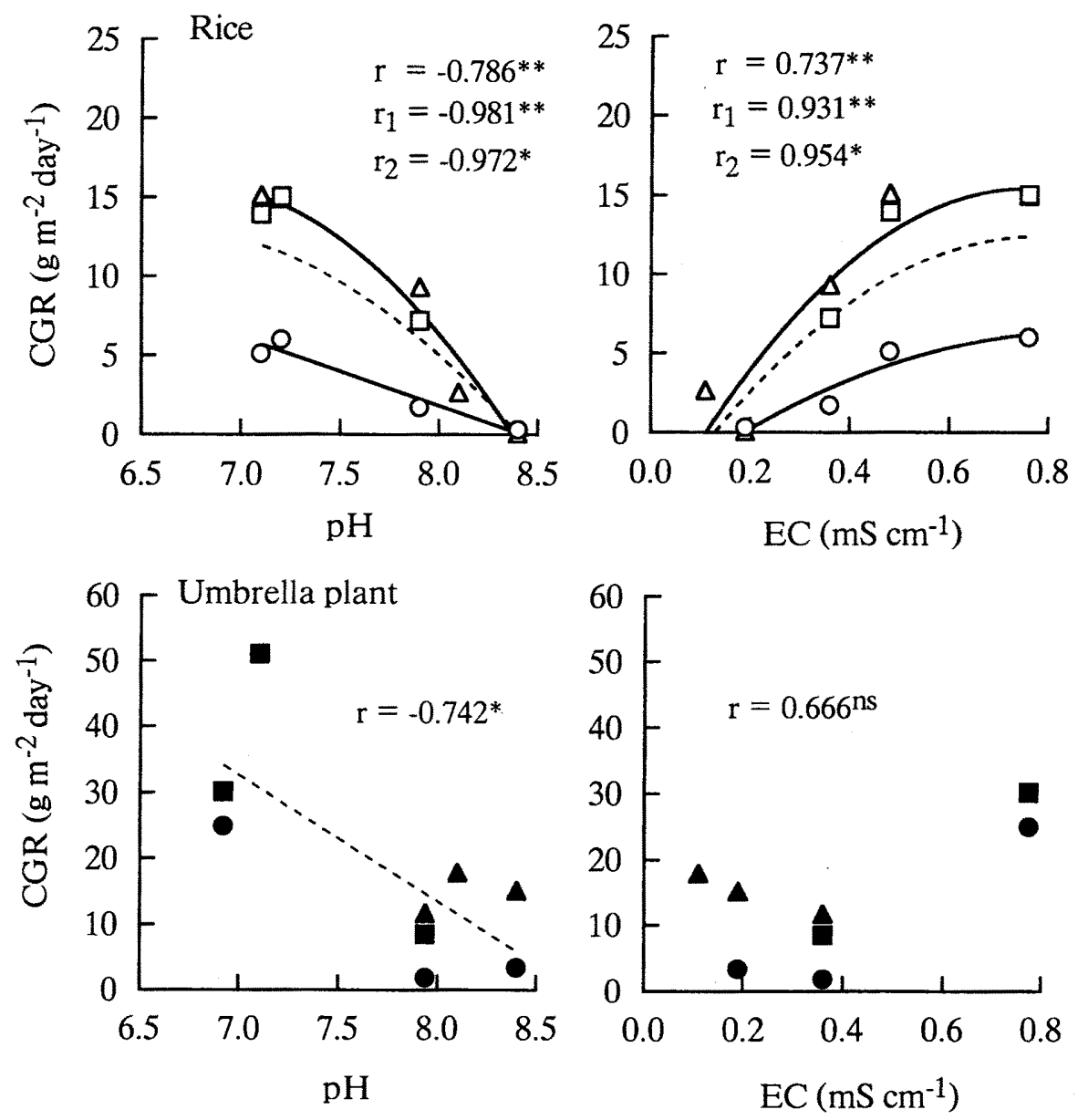

Fig. 4. Relationships between $\mathrm{pH}$ or $\mathrm{EC}$ and $\mathrm{CGR}$ in rice and umbrella plants grown at different eutrophication levels and different fertilizing levels (Experiments $\mathrm{A} \sim \mathrm{H}$ ).

Symbols are the same as those in Fig. 1. Refer to Table 1 for details of experiments A H. $r_{1}$, Correlation coefficient of plants grown with fertilizer; $r_{2}$, Correlation coefficient of plants grown without fertilizer; $r$, Correlation coefficient of total plants (dotted line). * and $* *$, Significant at $5 \%$ and $1 \%$ levels, respectively. 
so clearly, in umbrella plant. On the other hand, as shown in Fig. 5, there was a negative relationship between $\mathrm{pH}$ and $\mathrm{EC}$ in the waters. This implied that the two parameters played an inter-relational role in determining CGR.

In Table 3, the results of multiple regression analysis of $\mathrm{pH}$ and EC to CGR are shown together with the coefficients of two variables. The multiple regression coefficient, $R=0.786^{*}$, obtained in rice was significant, and a high value of $R=0.980^{* * *}$ was detected in fertilized plants. The equational explanation for CGR in rice was $62 \%$ on average, and it

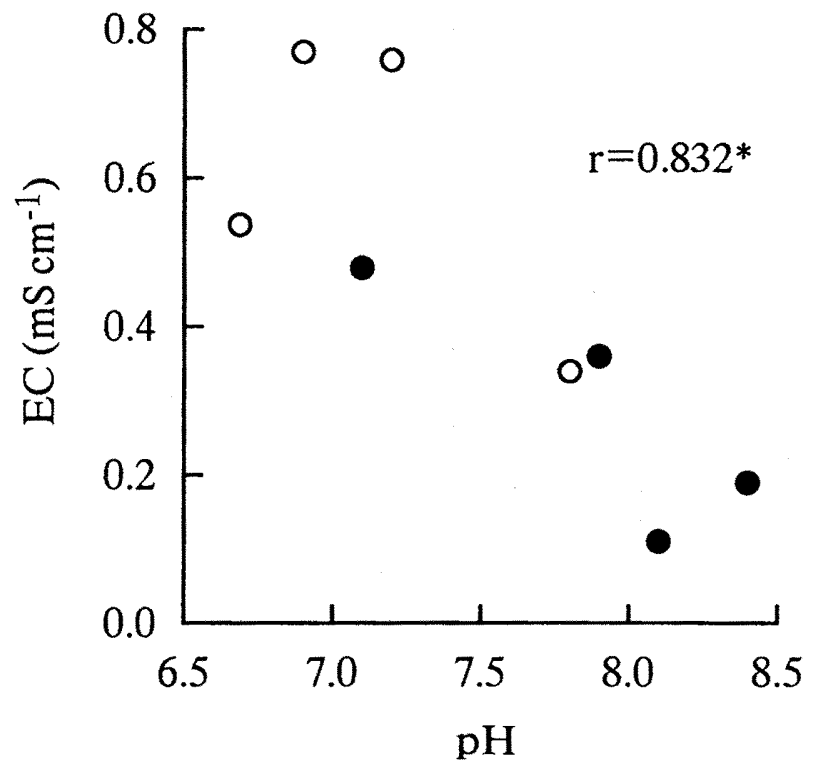

Fig. 5. Relationship between $\mathrm{pH}$ and EC in the water of experiments $\mathrm{A} \sim \mathrm{H}$.

$\bigcirc$, Open water area;, Closed water area

Table 3. Multiple regression analysis of CGR in experiments $A \sim H$.

\begin{tabular}{lllll}
\hline \multicolumn{1}{c}{ Species } & Multiple regression equation & $\mathrm{R}$ & \multicolumn{1}{c}{$\mathrm{R}^{2}$} & $\frac{\mathrm{RSPRC}}{\mathrm{X}_{\mathrm{i}}: \mathrm{X}_{2}}$ \\
\hline Rice & $\mathrm{Y}=-7.12 \mathrm{X}_{1}+4.70 \mathrm{X}_{2}+59.83$ & $0.786^{*}$ & 0.618 & $77.8: 22.2$ \\
$\quad$ Fertilizer & $\mathrm{Y}=-8.81 \mathrm{X}_{1}+6.30 \mathrm{X}_{2}+74.09$ & $0.980^{* * *}$ & 0.960 & $75.4: 24.6$ \\
No fertilizer & $\mathrm{Y}=-2.88 \mathrm{X}_{1}+4.26 \mathrm{X}_{2}+23.40$ & 0.992 & 0.985 & $63.3: 36.7$ \\
Umbrella plant & $\mathrm{Y}=-29.51 \mathrm{X}_{1}-39.12 \mathrm{X}_{2}+260.31$ & 0.808 & 0.653 & $63.2: 36.8$ \\
\hline
\end{tabular}

Refer to Table 1 for details of experiments $A \sim H$.

$\mathrm{Y}, \mathrm{CGR} ; \mathrm{X}_{1}, \mathrm{pH} ; \mathrm{X}_{2}, \mathrm{EC} ; \mathrm{R}$, Multiple regression coefficient; $\mathrm{R}^{2}$, Coefficient of determination; $\mathrm{Y}, \mathrm{CGR} ; \mathrm{X}_{1}$, $\mathrm{pH} ; \mathrm{X}_{2}, \mathrm{EC}$; $\mathrm{R}$, Multiple regression coefficient; $\mathrm{R}^{2}$, Coefficient of determination; RSPRC, Ratio of standard partial regression coefficient.

$*$ and $* * *$, Significant at $5 \%$ and $0.1 \%$ levels, respectively. 
Table 4. Effects of the application of acid fertilizer and iron fertilizer on growth and leaf photosynthesis in rice and umbrella plants measured at 38 days after transplanting (Experiment $E$ ).

\begin{tabular}{|c|c|c|c|c|c|}
\hline $\begin{array}{l}\text { Species } \\
\text { Cultivation }\end{array}$ & Treatment* & $\begin{array}{c}\text { TDW } \\
\left(\mathrm{g} \text { hill }^{-1}\right)\end{array}$ & $\begin{array}{l}\text { No. of stem } \\
\left(\text { No. hill }{ }^{-1}\right)\end{array}$ & $\begin{array}{c}\mathrm{Pn} \\
\left(\mu \mathrm{mol} \mathrm{m}^{2} \mathrm{~s}^{-2}\right)\end{array}$ & $\begin{array}{c}\mathrm{Chl} \\
\left(\mathrm{mg} \mathrm{dm}^{2}\right)\end{array}$ \\
\hline \multicolumn{6}{|l|}{ Rice } \\
\hline \multirow[t]{3}{*}{ Floating culture } & Control & $1.1 \mathrm{a}$ & $4.3 \mathrm{a}$ & $7.6 \mathrm{a}$ & $1.6 \mathrm{a}$ \\
\hline & Acid fertilizer & $4.4 b$ & $9.8 \mathrm{~b}$ & $21.8 \mathrm{~b}$ & $5.1 \mathrm{~b}$ \\
\hline & Iron fertilizer & $3.3 \mathrm{~b}$ & $8.3 b$ & $21.4 \mathrm{~b}$ & $5.1 b$ \\
\hline Paddy field & & $9.2 \mathrm{c}$ & $16.3 \mathrm{c}$ & $20.6 \mathrm{~b}$ & $4.9 \mathrm{~b}$ \\
\hline \multicolumn{6}{|l|}{ Umbrella plant } \\
\hline \multirow[t]{3}{*}{ Floating culture } & Control & $5.9 \mathrm{ab}$ & $7.3 \mathrm{a}$ & $20.8 \mathrm{a}$ & $5.5 \mathrm{a}$ \\
\hline & Acid fertilizer & $6.4 \mathrm{a}$ & $7.8 \mathrm{a}$ & $19.6 \mathrm{a}$ & $5.6 \mathrm{a}$ \\
\hline & Iron fertilizer & $6.2 \mathrm{a}$ & $7.8 \mathrm{a}$ & $20.7 a$ & $5.5 \mathrm{a}$ \\
\hline Paddy field & & $4.4 \mathrm{~b}$ & $5.3 b$ & $21.1 \mathrm{a}$ & $7.1 \mathrm{~b}$ \\
\hline
\end{tabular}

* Acid fertilizer and iron fertilizer were applied to the basal part of roots, respectively.

Refer to Table 1 for details of experiment $\mathrm{E}$.

TDW, Top dry weight; Pn, Leaf photosynthetic rate; Ch, Chlorophyll content.

was $96 \%$ in the fertilized condition. The ratios of the standard partial regression coefficients of $\mathrm{pH}$ and EC to CGR in rice were 77.8:22.2, or about 3:1. However, a significant equation was not obtained for umbrella plant.

Acid fertilizer application lowered $\mathrm{pH}$ from 7.1 to 5.1 when it was measured in the roots grown in the foam rubber fixed in a planting hole. As shown in Table 4, leaf photosynthetic rate and chlorophyll content were extremely reduced in rice to which the slow-release fertilizer alone was applied, while additional application of acid fertilizer or Fe fertilizer significantly raised the values of both parameters, resulting in a great improvement in shoot growth. Nevertheless, their shoot dry weight was significantly lower than that of paddy-grown rice, though the accurate comparison was impossible here because the fertilizing condition was not the same between paddy culture and floating culture.

On the other hand, umbrella plant was quite different in response to fertilizer application than was detected in rice. The fertilizer-dependent differences in photosynthetic rate and shoot dry weight of plants grown in the floating culture system were small, and the top dry weight and stem number of control plants grown without application of acid and Fe fertilizers were rather larger than those of the field-grown plants.

\section{DISCUSSION}

The floating culture system is regarded as a technique effectively utilized for the purpose of producing crop yield and solving the problem of water pollution simultaneously. On its practical use, clarifying the effects of water environmental conditions on plant production and water purification is important as basic information. We discussed here this subject from the physiological and ecological viewpoint with a 
focus on $\mathrm{pH}$ and $\mathrm{EC}$ situations in the eutrophied waters.

The plant production and water purification effect in rice and umbrella plants significantly varied with $\mathrm{pH}$ and nutrient concentration in the waters (Tables 2, 3; Fig. 4). This suggests that there are optimum ranges of $\mathrm{pH}$ and nutrient concentration for production and water purification in both rice and umbrella plants grown in the floating culture system.

In rice grown in the nutrients-enriched reservoir the yield was $542 \mathrm{~g} \mathrm{~m}^{-2}$. This is one of the noteworthy findings because such a high level yield was able to be obtained under a high $\mathrm{pH}$ condition ( $\mathrm{pH} 7.0$ ) over the optimum level for rice cultivation ( $\mathrm{pH} 5.5 \sim 6.0$ ), and the yield was comparable to that of rice grown in the paddy field. Song et al. (1991, 1995) also described the possibility of high yielding of hibrid rice grown in the floating culture system. The application of fertilizer enhanced not only plant growth but also the $\mathrm{N}$ purification effect (Fig. 3): the vigorous growth and rapid nutrient absorption of plants may realize the effective water purification.

On the other hand, in a reduced nutrient concentration both yield production and water purification effects were remarkably restricted (Fig. 3). When rice plants were grown in a highest $\mathrm{pH}$ and lowest $\mathrm{EC}$, the application of fertilizer was almost ineffective on the growth (Fig. 4). Under the condition like this, the applied fertilizer is not absorbed by plants and may cause a rise in ion concentration in the water.

The effects of $\mathrm{pH}$ and nutrient concentration on the growth and $\mathrm{N}$ absorption of float-cultured rice are demonstrated in the following two respects:

First, the plant growth and $\mathrm{N}$ absorption are strongly restricted by high $\mathrm{pH}$ (Table 3), which may induce a crucial Fe deficiency. However, even under such a condition, plant growth and leaf photosynthesis were markedly improved by applying Fe and acid fertilizers together with the basal-dressing fertilizer (Table 4). According to Susin et al. (1996), a high $\mathrm{pH}$ causes not only the precipitation of Fe ions dissolved in the water but also the decrease in Fe reduction ability of plant roots.

Second, the effect of $\mathrm{pH}$ on $\mathrm{N}$ absorption is variable with nutrient concentrations. As demonstrated by Glass et al. (1990), the energy-dependent $\mathrm{NO}_{3}$ absorption from the water having a low concentration of $\mathrm{NO}_{3}$ is inhibited by exposure to high $\mathrm{pH}(7.5)$. However, the absorption from the water of high $\mathrm{NO}_{3}$ concentrations is hardly influenced by $\mathrm{pH}$, because it occurs due to the passive diffusion driven by a concentration gradient. These findings suggest that rice plants cultured on the water of high nutrient concentration can absorb nutrients by passive diffusion even in high $\mathrm{pH}$ over 7.0, and this resulted in a grain yield increase to a high level comparable to that of rice grown in the paddy field (Fig. 3).

Umbrella plants grew more vigorously than did rice plants in any water conditions (Figs. 2, 4): the dry matter weight of umbrella plant was $981 \sim 11,338 \mathrm{~g} \mathrm{~m}^{-2}$, which was 172 $\sim 7.9$-times greater than those of rice. Umbrella plants showed superiority in the water purification ability through a wide range of $\mathrm{pH}$ and $\mathrm{EC}$ in the water. These are indispensable characteristics for plants effectively used for water purification. It seems to be interesting to make clear the functional characteristics in nutrient absorption in relation to $\mathrm{pH}$ and $\mathrm{EC}$ in this plant.

High $\mathrm{pH}$ and low EC conditions often simultaneously occur in the eutrophied closed waters (Fig. 5), causing the reduction in growth and nutrient absorption rate in 
float-cultured plants. The situations of $\mathrm{pH}$ and $\mathrm{EC}$ in the water depend on the assimilation and decomposition of microorganisms and phytoplankton both of which repeatedly proliferate and decline in the ecosystem. As described by Arita et al. (1998) and Matsuno et al. (1982), it is well known that $\mathrm{CO}_{2}$ in the water is used in photosynthesis of phytoplankton such as water bloom and algae, and this causes an increase in $\mathrm{pH}$. $\mathrm{N}$ and $\mathrm{P}$ is quickly absorbed by aquatic plants in an epilimnetic layer of the closed water area, and this may be responsible for a further reduction in nutrient concentration in the water.

When the floating culture is planed in a closed dam or reservoir with proliferating algae, the check of $\mathrm{pH}$ and nutrient concentrations is necessary in advance. Even under the water condition having high $\mathrm{pH}$ and low $\mathrm{EC}$, umbrella plant is expected to keep a significantly high nutrient absorption ability, which is also effective in removing algae through nutrient competition. In the open water area with continuous flow-in and flow-out of nutrients, the rise in $\mathrm{pH}$ with growth of algae does not seem to be so serious and less influential on crop growth. Under the condition like this the sufficient growth of rice may be expected in the floating culture system.

In order to improve the efficiency of water purification by plants grown in the floating culture system, a further study is required to find more suitable plants showing vigorous growth in the floating culture. As fundamental information, it is also necessary to understand their physio-ecological characteristics in growth function and response to water environments.

\section{REFERENCES}

Arita, M., H. Ikeda, M. Nakai, Y. Nakamura, K. Michioku and K. Murakami 1998 Environment in the hydrosphere (Suiken no Kankyo, in Japanese), ed. by M. Arita, Tokyo Denki Univ. Press, Tokyo

Glass, A. D. M., M. Y. Siddiqi, T. J. Ruth and T. W. Rufty 1990 Studies of the uptake of nitrate in barley. II. Energetics. Plant Physiol., 93: 1585-1589

Matsuno, T., M. Murabayashi, S. Asakura, M. Inoko, K. Urano, H. Tagawa 1982 Water Pollution and Soil Pollution (Suishitsuodaku, Dojoosen, in Japanese). ed. by The Association of security and technology, Kaibundo Press, Tokyo

Miyazaki, A., W. Agata, F. Kubota, Y. Matsuda and X. Song 1995 Bio-production and water cleaning by plant grown with floating culture system. 2. Water cleaning effects by the growth of several plant species. 6th International Conference on the Conservation and Management of Lakes-Kasumigaura' '95, 1: 560-563

Miyazaki, A., S. Tokuda, W. Agata, F. Kubota and X. Song 1997 On the photosynthetic production and water cleaning ability of Cyperus alternifolius L. grown by the floating culture system. Jpn. J. Crop Sci., 66 (2): 325-326

Song, X., H. Ying, M. Zhu and W. Wu 1991 A study on growing rice with floating method on the waters. Sci. Agric. Sinica, 24: 8-14

Song, X., W. Agata, W. Wu, H. Ying, M. Zhu and F. Kubota 1994 Bio-production and water cleaning by plants grown with floating culture system. 1. Characterization of floating culture from the view point of rice growth and yield. Jpn. J. Crop Sci., 63 (extra 2): 1-2

Song, X., W. Agata, G. Zou, W. Wu, H. Ying, Q. Yu, Y. Huang, F. Kubota and S. Muramoto 1995 Bio-production and water cleaning by plant grown with floating culture system. 1. Effects of floating culture area of rice plants on water quality criteria and bio-production. 6th International Conference on the Conservation and Management of Lakes-Kasumigaura '95, 1: 426-429

Susin, S., A. Abadia, J. A. Gonzalez-Reyes, J. J. Lucena and J. Abadia 1996 The pH requirement for in vivo activity of the iron-deficiency-induced turbo ferric chelate reductase. A comparison of the iron deficiency-induced iron reductase activities of intact plants and isolated plasma membrane fractions in sugar beet. Plant Physiol., 110: 111-123 